This item was submitted to Loughborough's Research Repository by the author.

Items in Figshare are protected by copyright, with all rights reserved, unless otherwise indicated.

\title{
The impact of corporate social and environmental practices on the cost of equity capital: UK evidence
}

PLEASE CITE THE PUBLISHED VERSION

https://doi.org/10.1108/IJAIM-11-2017-0141

\section{PUBLISHER}

Emerald Publishing Limited

VERSION

AM (Accepted Manuscript)

\section{PUBLISHER STATEMENT}

This paper was accepted for publication in the journal International Journal of Accounting and Information Management and the definitive published version is available at https://doi.org/10.1108/IJAIM-11-2017-0141.

\section{LICENCE}

CC BY-NC-ND 4.0

\section{REPOSITORY RECORD}

Ahmed, Ahmed H., Yasser Eliwa, and David M. Power. 2019. "The Impact of Corporate Social and Environmental Practices on the Cost of Equity Capital: UK Evidence". figshare.

https://hdl.handle.net/2134/33107. 


\title{
The Impact of Corporate Social and Environmental Practices on the Cost of Equity Capital: UK Evidence
}

\begin{abstract}
Purpose - There has been an ongoing call from various groups of stakeholders for social and environmental practices to be integrated into companies' operations. A number of companies have responded by engaging in socially and environmentally responsible activities, while others choose not to participate in these activities, which incur additional costs. The absence of consensus regarding the economic implications of social and environmental practices provides the impetus for this paper. This study aims to examine the association between corporate social and environmental practices (CSEP) and the cost of equity capital measured by four ex-ante measures using a sample of UK listed companies.
\end{abstract}

Design/methodology/approach - First, a review of the extant literature on CSEP is undertaken. Second, using a sample of 236 companies surveyed in 'Britain's Most Admired Companies' (BMAC) in terms of 'Community and Environmental Responsibility' during the period 2010-2014, four implied cost of equity capital proxies are estimated. The relationship between a company's cost of equity capital and its CSEP is then calculated.

Findings - We find evidence that companies with higher levels of CSEP have a lower cost of equity capital. This finding determines the significant role played by CSEP to help users to make useful decisions. Also, it supports arguments that firms with socially responsible practices have lower risk and higher valuation.

Practical Implications - The finding encourages companies to be more socially and environmentally responsible. Furthermore, it provides up-to-date evidence of the economic consequences of CSEP. The results should, therefore, be of interest to managers, regulators and standard-setters charged with developing regulations to control CSEP, as these practices are still voluntary in nature by companies.

Originality/value - To the best of authors' knowledge, this is the first study to investigate the association between CSEP of British companies and their cost of equity capital. Our study complements Ghoul et al. (2011), who examine the relationship between CSR and the cost of equity capital of US sample. We extend Ghoul et al. (2011) by using a sample of UK market after applying IFRS.

Keywords: CSEP; the cost of equity capital, the UK

Paper Type: Research Paper 


\section{Introduction}

In recent years, there has been a growing demand among firms’ stakeholders such as customers, employees, communities, governments and shareholders of companies to adopt policies regarding social and environmental issues (McWilliams and Siegel, 2000; El Ghoul et al., 2011; Hogan and Lodhia, 2011; Kimbro and Cao, 2011; Clarkson et al, 2013). More importantly, investors' awareness of incorporating sustainable activities within companies’ operations has grown exponentially over the years (Yu and Zhao, 2015; Kimbro and Cao, 2011). Alewine and Stone (2013) indicated that the costs and benefits of environmental initiatives impact management strategies and investing activities. In line with this, global investments managed according to socially and environmentally responsible principles have expanded dramatically, rising from \$13.3 trillion in 2012 to \$21.4 trillion in 2014 (Global Sustainable Investment Alliance, 2014).

Therefore, various attempts have been made to investigate the economic implications of CSR practices; however, the results, to date, have not been conclusive (Cochran and Wood, 1984; McGuire et al., 1988; El Ghoul et al. 2011; Xu et al. 2015). Such inconclusiveness has led to calls for further research in this area (Mishra and Suar, 2010) ${ }^{1}$. One strand of research discusses the link between CSR practices and company's performance and suggests that corporations will face a trade-off between the costs of adopting additional social, environmental and governance policies and the benefits from improved financial performance (McGuire et al., 1988; Dhaliwal et al., 2011; Plumlee et al., 2015).

Another strand of research argues that companies should play a positive role in communities in which they operate as wealth maximisation should not be the sole objective

\footnotetext{
${ }^{1}$ Indeed, it has been argued that the absence of any agreement over a link between social, environmental and governance practices and financial performance measures, may discourage companies from engaging in such practices (British Council et al., 2002).
} 
of companies (Tsoutsoura, 2004). Engaging in CSR activities involves costs which may be offset by benefits to a wide group of stakeholders (Tsoutsoura, 2004). In this regard, Hansen and Mowen (2007) have argued that achieving financial objectives of firms and resolving environmental issues are not mutually exclusive. Even shareholders may gain from a company's CSR activities if any expenditures linked with these activities are associated with a reduction in the company’s risk (Lee et al., 2013).

Although a sizeable body of literature exists on the link between corporate disclosure and the cost of equity capital (Souissi and Khlif, 2012) ${ }^{2}$, few studies focus on CSR. Only a handful of studies has sought to examine the relationship between CSR practices and the cost of equity capital and report mixed results including Connors and Silva-Gao (2008); Sharfman and Fernando (2008); Ghoul et al. (2011); Cheng et al. (2014); Xu et al. (2015); and Suto and Takehara (2017).

Therefore, the current study aims to examine the association between corporate social and environmental practices (CSEP) and the cost of equity capital using a sample of UK listed companies. In particular, it investigates the relationship between the extent to which CSEP is adopted by companies - as determined by BMAC and published in the Management Today - is associated with a lower cost of equity capital. It examines whether companies are rewarded for being socially and environmentally responsible with a lower cost of obtaining funds from equity.

Our study contributes to the extant literature in a number of ways. First, this study tests the association between CSEP and the cost of equity capital in the UK. In this regard, most of the previous studies that focus on the implication of CSR, test the association

\footnotetext{
${ }^{2}$ In a meta-analysis study, Souissi and Khlif (2012) indicated that the extant literature regarding the connection between the extent of financial disclosure and the cost of equity capital is inconclusive.
} 
between CSR disclosure and/or CSR practices and firm performance. However, few studies test the association between CSR practices and the cost of equity, and primarily been conducted in the US (Sharfman and Fernando, 2008; Ghoul et al., 2011), where CSR practices are subject to the different regulatory environment. In this regard, although the UK and the US share some common features, e.g., both have a common law system, dispersed ownership, strong investor rights, strong legal enforcement and large equity markets (Nobes et al., 2008; Leuz et al., 2003; Eliwa et al., 2016), there are differences. For example, the institutional investors have a higher market share in the UK (82\% of the whole market) compared to the US (50\% of the whole market) (Investment Company Institute, 2010; Office for National Statistics, 2010). Also, the composition of those institutional investors differs in both countries. In the UK, both Insurance firms and pension funds dominate the market, while, in the US, mutual funds and investment advisors are the largest institutional investors. The differentiation between the types of institutional investors is important because they have different performance strategies and hence provide different pressures on firms. Particularly, the pension funds and insurance firms that lead the London Stock Exchange have long-term payout responsibilities; therefore, they might more willingly to implement a long-term plan for risks and opportunities for their portfolio firms (Aguilera et al., 2006). Also, the UK government encouraged long-term risks plans as it required, at least, one type of institutional investors, i.e., pension funds, to disclose the extent to which social, environmental and ethical considerations are taken into account in making investment portfolios (Williams and Conley, 2005; Aguilera et al., 2006). This might motivate UK firms to adopt a clear CSR strategy to attract those investors, which might lead to a decrease in the cost of equity capital.

Another salient difference between these two countries is the greater attention being paid in the UK by firms and institutional investors to the social and environmental risks 
(Aguilera et al., 2006). Previous studies provide different explanations for this greater attention in the UK to CSR issues. Solomon et al. (2004, p.557) identify three reasons: "a general increase in concerns about ethics in British society; heightened awareness of risk and risk management; and the growth in media exposure concerning CSR.” They concluded that CSR issues are less advanced in the US compared with the UK (Aguilera et al., 2006).

Based on these differences, we argue that the UK regulation and institutional environment provide an interesting setting for further exploration of whether CSEP is an information risk in the UK with the expectation of a strong negative association between CSEP and the cost of equity, which has not to our knowledge been examined in prior work.

Second, most of the extant literature focuses on CSR disclosure (Dhaliwal et al., 2011; Clarkson et al., 2013; Plumlee et al., 2015). However, our study test CSR practices in the UK context. This is a significant contribution taking into account the fact that CSR disclosure is just an indication of what firms say they are doing, which could be entirely different from their real practices. Third, our findings provide up-to-date evidence that CSEP is reflected in the cost of equity capital, as the absence of any evidence that link between CSEP and financial performance measures may discourage companies from engaging in such practices. Therefore, the results reported in this study might encourage companies to start engaging in more socially and environmentally responsible activities.

The remainder of this paper is organised as follows. Section 2 highlights the theoretical reasoning underpinning the present study. Section 3 reviews the extant literature in the area and state the research hypotheses, while details about the research methodology and data collection process are presented in Section 4. The results are reported in Section 5. 
Finally, Section 6 concludes the paper by summarising the findings of the existing research and identifying future avenues to explore.

\section{Literature review and hypothesis development}

Theoretical literature has devoted itself to study the economic consequences of CSR and its effects on the investors' required return. In particular, the cost of equity capital is related to CSEP in several aspects. First, if CSEP effect company's risk, then socially and environmentally responsible companies should benefit from lower equity financing costs. Second, companies adopting active CSR, corporate governance policies and high quality accounting standards can affect their cost of equity capital through a reduction in agency and information asymmetry problems (Amihud and Mendelson, 1986; Diamond and Verrecchia, 1991; Easley and O’Hara, 2004; Botosan, 2006; Chen et al., 2009; Lang et al., 2012). Third, the cost of equity represents the required rate of return on investments, so it is a crucial factor in firms' long-term investment decisions. Consequently, examining the relationship between CSR and the cost of equity should help managers comprehend the impact of CSR investment on firms' financing costs, and hence has significant implications for strategic planning (El Ghoul et al., 2011). Such literature often used two theories to explain the potential association between CSEP and the cost of equity capital. These include agency theory and signalling theory.

Agency theory is based on the notion that agency problems arise mainly because of the separation between ownership and management (Jensen and Meckling, 1976). Agency costs are incurred when management behaves to the financial loss of the shareholders (Ness and Mirza, 1991). On the other hand, because agency costs are borne by the management (Jensen and Meckling, 1976), they like to be perceived to be performing in maximising shareholders 
wealth. Engaging in social and environmental practices provide management with the opportunity to be seen to be performing in such manner. Agency theory suggests that firms may use different techniques to alleviate the conflict of interest between management and interested parties (Sun et al., 2010), engaging in social and environmental practices are considered to be amongst these techniques. In this context, Clarkson et al. (2011) indicated that companies with good social and environmental practices might enjoy a reduction in regulatory risk, which in turn could affect valuation through lower discount rates and cost of capital (Klassen and McLaughlin, 1996; El Ghoul et al., 2011). In this context, Sun et al. (2010) pointed out that “CSR activities provide a more accurate risk assessment for investors and this, in turn, will give access to external financing at the possible lowest cost” (p. 684).

The other strand of research uses signalling theory to explain the association between CSEP and the cost of equity. In particular, signalling theory is concerned with alleviating the information asymmetry problem between insiders and outsiders (Morris, 1987). It revolves around the idea that firms that are performing well have an incentive to distinguish themselves from those performing poorly (Craven and Marston, 1999). In this regard, Gray (2005) indicated that companies engaging in CSEP are primarily concerned with signalling the quality of its management. Socially and environmentally responsible businesses have an incentive to signal such engagement to the market. In the same context, CSEP provides a clear signal to investors and other stakeholders that the company is not only concerned with maximising shareholders wealth but also contributing to the prosperity of the communities in which they operate. This, in turn, could have a positive impact on their market value (Sun et al., 2010). Good corporate social performance helps a company to gain a reputation for reliability from capital markets, which could help companies getting cheaper capital. On the 
other hand, Belal and Cooper (2011) indicated that firms with a negative CSR performance prefer to stay silent, as shedding light on these practices may harm their reputation.

Empirically, most of the researchers focus on the association between CSEP and firm performance and they have not reported conclusive results regarding this relationship. For example, Margolis et al. (2009) provide a review of 251 studies that have examined the association between engaging in CSEP and financial performance. They revealed a small positive relationship between CSEP and financial performance. Another strand of the CSR literature has examined the relationship between CSEP and firms value. For instance, Jo and Harjoto (2011) reported a positive relationship between CSR engagement and company value as measured by industry-adjusted Tobin's Q.

However, there are few studies test the association between CSR and the cost of equity capital. These studies can be summarised into two groups. Those focus on CSR disclosure and the CSR practices.

For the first group of research, Richardson and Welker (2001) test the relationship between financial and social disclosures and the cost of equity capital for a sample of Canadian firms for the period 1990-1992. The study found a negative link between the financial disclosure and the cost of equity capital, while the opposite was reported concerning social disclosure. Similarly, Dhaliwal et al. (2014) examined the link between CSR disclosure and the cost of equity capital in an international context covering 31 countries. The study found a negative association between CSR disclosure and the cost of equity capital. Harjoto and Jo (2015) investigated the impact of overall, mandatory and voluntary CSR on a number of variables including the cost of equity capital for a sample of US firms during 1993-2009. The results showed that overall and legal CSR intensities reduce the cost of equity capital, while normative CSR was found to increase the cost of equity capital. In a recent study, Li 
and Liu (2017) explore the association between the quality of CSR disclosure and the cost of equity capital for A-shares Chinese listed firms during 2008-2014. The results show that companies with enhanced CSR disclosure have a lower cost of equity capital.

Moving to the second group of research, Connors and Silva-Gao (2008) investigated the effects of environmental practices based on chemical emissions and a company's cost of equity capital. The sample included companies drawn from the electric and chemical industries during the years 2001-2007. The study found that shareholders charged companies with higher levels of chemical emissions a higher cost of equity capital. Similarly, Sharfman and Fernando (2008) examined whether better environmental risk management was associated with a lower cost of equity capital using a sample drawn from the S\&P 500. The study reported that improved environmental performance was negatively associated with the cost of equity capital.

Also, El Ghoul et al. (2011) examined the effect of CSR practices on the cost of equity capital for a sample of 12,915 US firm-year observations. KLD ratings were used as a proxy for CSR performance, while a number of methods were employed to determine firm's ex-ante cost of equity capital. The findings revealed that investments in socially and environmentally responsible activities as well as in product strategies have a significant impact on reducing firm's cost of equity capital. Furthermore, the study found that companies belonging to the so-called "sin industries", namely, tobacco and nuclear power, have higher costs of equity capital.

Cheng et al. (2014) investigated the relationship between enhanced CSR performance and access to finance using a sample from 49 countries covering the period 2002-2009. The findings revealed that companies with better CSR performance face significantly lower 
capital constraints. Xu et al. (2015) examined the association between CSR practices and the cost of equity capital for a sample of Chinese firms. The results indicated that investments in CSR activities contribute significantly in reducing firm's equity financing costs. The study also reported that the association between CSR and the cost of equity capital is more significant in recession periods.

Yu and Zhao (2015) examined the impact of sustainability on firm value using the Dow Jones Sustainability Index (DJSI) during 1999-2011. The study found a positive link between sustainability performance and firm value. Also, Suto and Takehara (2017) examined the link between corporate social performance (CSP) and the cost of capital for a sample of Japanese firms covering the period 2008-2013. The study found insufficient evidence of a negative association between the extent of CSP and the cost of capital.

To sum up, it appears from this literature that the relationship between CSR disclosure level or practices and the cost of equity capital is mixed. Also, it is clear that most of the research that tests the association between CSR practices and the cost of equity capital have been conducted in the US (e.g., El Ghoul et al., 2011). Therefore, this study aims to test the association between CSR practices and the cost of equity capital in the UK. In this regard, the institutional investors have higher market share in the UK (82\% of the whole market) compared to the US (50\% of the whole market) (Investment Company Institute, 2010; Office for National Statistics, 2010). Also, the composition of those institutional investors differs in both countries. In the UK, both Insurance firms and pension funds dominate the market, whilst, in the US, mutual funds and investment advisors are the largest institutional investors. In this context, Guenster et al. (2011) indicated that institutional investors have preferences for investing in companies engaging in socially and environmentally responsible activities. Furthermore, El Ghoul et al. (2011) argued that socially oriented investors do not prefer to 
add any poor CSR firms to their investment portfolios. Based on the preceding discussion, it is expected to find a strong negative association between CSEP, measured by the Britain's Most Admired Companies (BMAC) ratings, and the cost of equity capital. Therefore, this study proposes the following hypothesis:

\section{H1: CSEP is negatively associated with company's cost of equity capital.}

\section{Sample Selection and Methodology}

The initial sample encompasses all the 236 companies covered by Management Today BMAC 3 2010-2014 surveys regarding ‘community and environmental responsibility’. After deleting companies with missing data, our final sample includes 227 companies listed on the London Stock Exchange. We use the Thomson Reuters DataStream database to obtain the control variables. We also use the $I / B / E / S$ Database to gather proxies for implied costs of equity capital (see Figure 1). The final sample consists of 547 company-year observations. The outliers of all variables are winsorized to the 5 and 95 percentiles.

\subsection{Variables Measurement}

\subsubsection{The cost of equity capital}

Empirically, the cost of equity capital can be estimated by using two approaches: (1) the ex-post cost of equity capital models, which can be estimated by reference to market data such as a price-earnings ratio or realised returns. (2) The ex-ante cost of equity capital models, which can be estimated by reference to analysts' forecasts by either the residual income model or dividend discount model. This approach has been used by many previous

\footnotetext{
${ }^{3}$ This survey is the British equivalent of the Fortune survey and is based on the same methodology. It was first published in the Economist in 1989 and from 1994 onwards it is published in Management Today (Salama, 2005).
} 
studies (e.g., Claus and Thomas, 2001; Gebhardt et al., 2001; Botosan and Plumlee, 2002; Gode and Mohanram, 2003; Easton, 2004; Dhaliwal et al., 2006; El Ghoul et al., 2011).

In particular, this study follows Dhaliwal et al. (2006) and Ghoul et al. (2011) in estimating the cost of equity capital in June of each year based on the ex-ante/implied measures. To do so, we extract from the $I / B / E / S$ Database the analysts' forecast data recorded in June for the sample that has positive 1- and 2-year-ahead consensus earnings forecasts and a positive long-term growth forecast. Then, we estimate the cost of equity capital using the average of three models $\left(r_{M E A N}\right)$ : the price-earnings-growth ratio model $\left(r_{P E G}\right)$ (Easton, 2004); the modified price-earnings growth ratio (Easton, 2004) $\left(r_{M P E G}\right)$ and the modified economy-wide growth model (Gode and Mohanram, 2003) $\left(r_{G M}\right)$. This measure seeks to reduce biases and measurement errors in the regression analysis by averaging the different cost of equity capital estimates (Hail and Leuz, 2006) (See Figure 1: the measurement of the implied cost of equity capital proxies).

[Insert Figure 1 here]

\subsubsection{Corporate social and environmental performance (CSEP)}

The methodology employed in the present study is similar to that adopted by Toms, 2002; Hasseldine et al., 2005; Salama, 2005; Sun et al., 2010 and Salama et al., 2011. Corporate social and environmental performance (CSEP) data was collected from the BMAC surveys covering the period from 2010 to 2014. Each of these surveys contains all the FTSE100 British companies and, on average, 90\% of the top 200 companies by market capitalisation. The sample companies are the largest by market capitalisation from each of 26 sectors. Each year BMAC survey asks senior executives from 260 British companies and senior specialist business analysts to give a rating of the performance of each company, other than their own in the case of executives, within their industrial sector. They are asked to give 
a score ranging from 0 (poor) to 10 (excellent) for each of the nine characteristics ${ }^{4}$, including community and environmental responsibility, the primary focus of the present study. The community and environmental responsibility ${ }^{5}$ employed in the current study as a proxy to determine CSEP. It is expected the coefficient on the CSEP variable to be negative, which indicates that investors attach higher risk assessments to companies with smaller values of CSEP. For control variables,

\subsubsection{Control variables}

The hypothesised association between CSEP and the cost of equity capital is based on the assumption that other variables are held constant. Previous studies suggest four control variables that may affect the cost of equity capital: firm size (Size), CAPM Beta (Beta), leverage and growth (Francis et al., 2005; Gray et al., 2009; Eliwa et al., 2016). We measure Size as a log of a company's total assets in year t. Beta is measured using five-year rolling beta calculated from the CAPM model using monthly data. Leverage is a company's debt deflated by total assets in year t. Growth is the log of one plus the company's growth in book value of equity over the previous 5 years.

According to the literature, we expect positive coefficients for beta and leverage as highrisk companies financed with much debt are supposed to have a higher cost of equity capital. By contrast, the literature suggests that the coefficients for company size and growth should be positive since big companies or high growth companies can typically raise equity funds more cheaply (Francis et al., 2005; Gray et al., 2009; Eliwa et al., 2016).

\footnotetext{
${ }^{4}$ These characteristics are quality of management, financial soundness, quality of goods and services, ability to attract, retain and develop top talent, values as a long-term investment, innovation, quality of marketing, community and environmental responsibility and use of corporate assets.

5 The CER variable is the average score derived from the individual ratings of executives and analysts combined.
} 


\section{Empirical Tests and Results}

\subsection{Descriptive Statistics}

Table 1 reports the descriptive statistics regarding the CSR, the cost of equity capital $\left(r_{M E A N}\right)$ and company characteristics for the sample companies. The mean value of $r_{M E A N}$ is 0.11 while its median is 0.10 . The CSEP index has mean and median values that are similar; the average is 6.2 and the median is 6.3. Moreover, Table 1 reports summary information for the relevant financial variables. The typical company in the sample had total assets of about $£ 5,200$ million and sales of $£ 3,900$ million. The mean level of equity was about $£ 1,900$ million, it had a Beta of just below 1.0 and a mean level of leverage is 0.21 . Thus, the average company in the sample was large with a sizable amount of assets and financed mainly by equity capital.

Table 2 reports the correlations amongst $r_{M E A N}$, CSEP, and the control variables. The results show a significant negative relationship between $r_{M E A N}$ and CSEP suggesting that relatively high CSEP index companies can raise funds at a lower cost of equity in the capital market. For the control variables, we find significant positive correlations between $r_{M E A N}$ and Beta and size, with a sizeable correlation between Beta and $r_{M E A N}(0.3044)$. Also, we find a positive correlation between $r_{M E A N}$ and leverage but the coefficient was not significant. We find, also, a significant negative association between $r_{M E A N}$ and growth. This result is consistent with prior studies on the correlation between the cost of equity capital and Beta (e.g., Francis et al., 2005; Gray et al., 2009). The correlations among CSEP and control variables range between -0.19 to 0.23 which indicates that no multicollinearity problem is present among the independent variables ${ }^{6}$. All of the correlations are consistent with prior

\footnotetext{
${ }^{6}$ Variance Inflation Factors (VIFs) were calculated to measure the severity of any multicollinearity in subsequent regression analyses. It is an indicator of severe multicollinearity problems, if VIFs score is above ten. The results showed that none of the VIFs were above two, this suggests that no multicollinearity problem in the regression analyses.
} 
studies except the correlation between the cost of equity capital and leverage, although it had the correct sign, it is not significant. One would expect that highly geared companies have to pay a higher cost of equity capital - presumably because of the higher risk to investors from the greater use of debt. The debt capital has a prior claim on the income of a company before any dividends can be paid and usually has priority above equity in the event of a company's liquidation.

\author{
[Insert Table 1 here] \\ [Insert Table 2 here]
}

\title{
5.2 Multivariate Analysis
}

In this section, we document the results of the primary tests of the relationship between a company's cost of equity capital and its CSEP performance after taking account of control variables. The analysis uses $r_{M E A N}$ to estimate the cost of equity capital. CSEP scores were obtained from the Management Today website, while control variables are collected from DataStream. The control variables are Beta, Size, leverage, and growth (e.g., Francis et al., 2005; Gray et al., 2009; Eliwa et al., 2016). Moreover, we use the time-series standard errors regression, which introduced by Fama and MacBeth (1973), to alleviate concerns about cross-sectional dependencies in the sample. The following equation is estimated to test our research hypothesis:

$$
r_{M E A N_{c, t}}=\partial_{0}+\partial_{1} \operatorname{CSEP}_{c, t}+\partial_{2} \text { Beta }_{c, t}+\partial_{3} \text { Size }_{c, t}+\partial_{4} \text { Growth }_{c, t}+\partial_{5} \text { Leverage }_{c, t}++\delta_{c}[1]
$$

Where: $r_{M E A N}$ is the average of three implied cost of equity capital proxies. These proxies are the price-earnings growth ratio model $\left(r_{P E G}\right)$ (Easton, 2004); the modified price-earningsgrowth ratio (Easton, 2004) $\left(r_{M P E G}\right)$ and the modified economy-wide growth model (Gode and Mohanram, 2003) $\left(r_{G M}\right)$. CSEP is the corporate social and environmental responsibility 
of a company as indexed in the BMAC published in Management Today. Beta is the fiveyear rolling beta calculated from the CAPM model using monthly data; Size is log of a company's total assets in year $t$; Growth is the log of one plus the company's growth in book value of equity over the previous 5 years; Leverage is a company's debt deflated by total assets in year $t$.

Table 3 provides both the mean of the yearly coefficients from estimating equation (1) and their statistical significance. The results in Panel A of this table show a negative association between CSEP and the cost of equity capital which is significant at the $1 \%$ level; the coefficient estimate is -0.0010 (t-statistic $=5.10$ ). This finding suggests that companies with higher quality CSEP ratings in BMAC have a lower cost of equity capital compared to their lower quality CSEP counterparts. We interpret these results as follows: as the CSEP index declines, the amount that investors are ready to pay for a pound of earnings falls as well, implying a higher cost of equity capital for such companies. Thus, there is support for the first hypothesis $\left(\mathrm{H}_{1}\right)$. Also, this finding supports our notion that investors, in the UK, pay more attention to the CSR and consider it as a risk factor. Moreover, it is consistent with prior studies which claimed that companies with good SEP might enjoy a reduction in risks, which in turn could affect valuation through lower discount rates and the cost of capital (e.g., Klassen and McLaughlin, 1996; Sun et al., 2010; El Ghoul et al., 2011; Clarkson et al., 2011). Finally, this finding supports the notion CSEP could be considered as one of the techniques that might use to decrease the conflict of interest between management and investors (agency theory) (Sun et al., 2010).

Engaging in social and environmental practices provide management with the opportunity to be seen to be performing in such manner. Agency theory suggests that firms may use different techniques to alleviate the conflict of interest between management and interested 
parties (Sun et al., 2010), engaging in social and environmental practices are considered to be amongst these techniques.

In terms of the control variables, the results show that $r_{M E A N}$ is significantly positively associated with a company's beta. However, $r_{M E A N}$ has an insignificant negative relationship with a company's leverage. The Beta result is consistent with the findings from prior studies.

When the Newey and West (1987) standard errors from the pooled regression model are used, similar findings emerge in Panel B of Table 3. Once heteroscedasticity and autocorrelation effects are controlled for, the sign and significance of the previous results remain unchanged. Panel $\mathrm{B}$ of Table 3 reports the coefficient estimates and statistical significance of a pooled regression for the same sample. The pooled regressions results are similar to the results of the mean annual regressions using the Fama and MacBeth (1973) method; the coefficient estimate for the CSR variable is -0.0010 (t-statistic $=4.91$ ).

Finally, we test the association between the cost of equity capital and CSEP on a yearly basis from 2010 to 2014; we find a significant negative relationship between the two variables in years 2010, 2012, 2013 and 2014. However, we find a negative but insignificant relationship between the two variables in the year 2011. The $\mathrm{R}^{2}$ for the regressions also vary from year to year; the statistics varied from a low of $4 \%$ in 2012 to a high of $21 \%$ in 2010 . So, the annual analysis indicates that the relationship between CSEP and the cost of equity capital varies over time.

[Insert Table 3 here]

\subsection{Robustness Checks}

Different sensitivity tests are performed on the results. First, in addition to the mean estimate of the cost of equity capital $\left(r_{M E A N}\right)$, we use three other proxies for the cost of equity 
capital derived from the dividend valuation model of Gordon (1959). These are the priceearnings growth ratio (Easton, 2004), the modified price-earnings growth ratio (Easton, 2004), the modified economy-wide growth model (Gode and Mohanram, 2003). Equation (1) is re-estimated by replacing the $r_{M E A N}$ with the three ex-ante measures of the cost of equity capital and the results are reported in Table 4. The results show a significantly negative association between the cost of equity capital and CSEP. This finding suggests that companies with a higher quality of CSEP have a lower cost of equity capital compared to their lower quality CSEP counterparts, which is consistent with the main tests. For control variables, the results show a significant positive association between the cost of equity capital and Size, Beta and growth; however, the results show an insignificant negative association between the cost of equity capital and leverage.

[Insert Table 4 here]

Second, we use panel regressions to test the relationship between all of the implied costs of equity capital and CSEP; Table 5 reports the results. Based on the Hausman test, the fixed effects approach was deemed to be more appropriate than the random effects model. The results of fixed effects regressions show significant negative associations between CSEP and all of the cost of equity capital proxies, which is consistent with the results obtained from the primary tests. The size of the CSEP coefficient is lowest, in absolute terms, when $r_{P E G}$ is the dependent variable (-0.00068) and highest, in absolute terms, when $r_{G M}$ is the dependent variable (-0.0011).

\section{[Insert Table 5 here]}

Third, we control for a potentially endogenous association between CSEP and the cost of equity capital using the 2SLS technique on the pooled sample (results not reported). The 
results of the 2SLS regression are largely consistent with the OLS regression that reported in Table (3).

\section{Discussion and Conclusion}

CSEP has been integrated into the business practices of most of the international companies, so there is a considerable increase in the number of studies that have investigated the economic implications of such practices over the past few years. In particular, the association between CSEP and companies' financial performances has been the subject of an ongoing investigation in the literature. These relatively small numbers of studies, which have examined the association between CSEP and the cost of equity capital, have yielded mixed results. The current study investigates the relationship between CSEP as measured by 'Britain’s Most Admired Companies’ list and the cost of equity capital measured using four proxies for UK listed companies during the period 2010-2014. Our results indicate that there is a significant negative association between CSEP and the cost of equity capital. This finding suggests that company investment in improving CSEP contributes significantly to reductions in companies' cost of equity. Furthermore, the reported results indicate that companies with an active CSEP agenda can gain a sustainable competitive advantage by reducing the adverse impact of their activities on society or the surrounding environment while lowering their cost of equity financing in the UK. This finding supports arguments in the literature that companies with socially responsible practices have higher valuations and lower risk levels: e.g., Connors and Silva-Gao (2008); Sharfman and Fernando (2008); Dhaliwal et al. (2011); and Bonetti et al. (2014).

Since the extant literature linking CSEP and the cost of equity capital is scarce (Jiao, 2010), the current paper contributes to the work in this area where there is a dearth of prior 
investigations in countries outside of the USA. Furthermore, the current study provides recent evidence concerning the economic implications of CSEP. The data is up-to-date and from a source that has not been investigated in the past. The results of the present study have a number of practical implications for both national (UK) and international corporations. For example, the results provide some insights that should encourage more companies to engage in socially and environmentally responsible activities. It indicates that it does matter to engage in such activities, as it seems that investors place a premium on "good" CSEP companies by demanding relatively lower returns on their stocks, resulting in a lower cost of equity capital.

Also, it encourages managers of low CSEP firms to increase investments in CSRrelated activities, as doing so may reduce their cost of equity and enhance the value of the firm for shareholders. On the other hand, firms with high CSEP should actively disclose information about their CSR activities to the public. These firms can attract more socially responsible investors by projecting their positive image as a responsible corporate citizen to investors and other stakeholders, which will be reflected in their cost of equity capital.

Moreover, the findings of the current study should be of interest to regulators and standard-setters charged with developing standards and guidelines charged with developing regulations to manage CSEP, as these practices are still voluntary in nature with companies having discretion over the extent and quality of such practices.

In line with the global call for more social and environmental businesses, more studies are required in this area. First, a useful expansion of this research could focus on examining the factors that influence companies' decisions to engage in social and environmental practices, as these practices vary significantly amongst the sample companies. Taking into 
account the value of interested parties' views concerning these practices, a second extension of the current analysis could examine why investors might demand a lower return from investing in companies with a good CSEP track record. A third expansion might involve a cross-country comparative analysis of CSEP in Europe; while analyses of previous literature across the broad field of accounting has tended to group European nations together, there are many differences in economic, cultural and political contexts and international replication of the work could yield valuable insights.

\section{References}

Aguilera, R. V., Williams, C. A., Conley, J. M. \& Rupp, D. E. (2006) Corporate governance and social responsibility: A comparative analysis of the UK and the US. Corporate Governance: An International Review 14(3), 147-158.

Alewine, Hank C. \& Stone, Dan N. (2013) How does environmental accounting information influence attention and investment? International Journal of Accounting \& Information Management, 21 (1), pp.22-52.

Barnea, A., \& Rubin, R. (2010) Corporate Social Responsibility as a Conflict between Shareholders. Journal of Business Ethics 97(1), 71-86.

Bonetti, P., Cho, C. H., Michelon, G. \& Tanaka, Y. (2014) Environmental disclosure and the Cost of Capital: Evidence from the Fukushima Nuclear Accident. Working Paper.

Botosan, C., (1997) Disclosure level and the cost of equity capital. The Accounting Review 72, 323-349.

Botosan, C. (2006) Disclosure and the Cost of Capital: What Do We Know? Accounting and Business Research 36(S1), 31-40.

Botosan, C. A. \& Plumlee, M. A. (2002) A re-examination of disclosure level and the expected cost of equity capital. Journal of accounting research, 40(1), 21-40.

Botosan, C., \& Plumlee, M. (2005) Assessing Alternative Proxies for the Expected Risk Premium. The Accounting Review 80, 21-53.

Botosan, C., Plumlee, M., \& Wen, H. (2011) The relation between expected returns, realized returns, and firm risk characteristics. Contemporary Accounting Research 28 (4), 1085-1122.

Chen KCW., Chen Z., \& Wei KC. (2009) Legal protection of investors, corporate governance, and the cost of equity capital. Journal of Corporate Finance 15, 273289.

Cheng, B., Ioannou, I. \& Serafeim, G. (2013) Corporate Social Responsibility and Access to Finance. Strategic Management Journal, 35, 1-23.

Clarkson, P.M., X. Fang, Y. Li., \& Richardson, G. (2013) The relevance of environmental disclosures: are such disclosures incrementally informative? Journal of Accounting and Public Policy 32 (5), 410-431.

Clarkson, P., Li, Y., Richardson, G., \& Vasvari, F. (2011) Does it really pay to be green? Determinants and consequences of proactive environmental strategies, Journal of Accounting and Public Policy 30, 122-144. 
Clarkson, P., Li, Y., Richardson, G., \& Vasvari, F. (2008) Revising the relation between environmental performance and environmental disclosure: an empirical analysis. Accounting, Organizations, and Society 33, 303-327.

Clarkson, P., Li, Y., \& Richardson, G. (2004) The market valuation of environmental expenditures by pulp and paper companies. The Accounting Review 79, 329-353.

Claus, J. \& Thomas, J. (2001) Equity premia as low as three percent? Evidence from analysts' earnings forecasts for domestic and international stock markets. The journal of finance, 56(5), 1629-1666.

Cochran, P. L., \& Wood, R. A. (1984) Corporate Social Responsibility and Financial Performance. Academy of Management Journal 27 (1), 181-191.

Coller, M., \& Yohn, T. (1997) Management forecasts and information asymmetry: an examination of bid-ask spreads. Journal of Accounting Research 35 (2), 181-191.

Collins, D., Maydew, E., \& Weiss, I. (1997) Changes in the value-relevance of earnings and book value over the past forty years. Journal of Accounting and Economics 24, 39-67.

Connors, E., \& Silva-Gao, L. (2008) The impact of environmental risk on the cost of equity capital: evidence from the toxic release inventory. Working Paper.

Cormier, D., Magnan, M., \& Morard, B. (1993) The impact of corporate pollution on market valuation: some empirical evidence. Ecological Economics 8, 135-155.

Cormier, D., \& Magnan, M. (1997) Investors' assessment of implicit environmental liabilities: an empirical investigation. Journal of Accounting and Public Policy 16, 215-241.

Craven, B. M. \& Marston, C. L. (1999) Financial Reporting on the Internet by Leading UK Companies. European Accounting Review 8(2), 321-333.

De Franco, G., Hope, O., \& Larocque, S. (2012) The effect of disclosure on the payperformance relation. Journal of Accounting and Public Policy.

Dhaliwal, D., Li, O., Tsang, A., \& Yang, G. (2011) Voluntary non-financial disclosure and the cost of equity capital: The initiation of corporate social responsibility reporting. The Accounting Review 86 (1), 59-100.

Dhaliwal, D., Li, O., Tsang, A., \& Yang, G. (2014) Corporate social responsibility disclosure and the cost of equity capital: The roles of stakeholder orientation and financial transparency. Journal of Accounting and Public Policy, 33, 328-355.

Easton, P. D. (2004) PE ratios, PEG ratios, and estimating the implied expected rate of return on equity capital. The Accounting Review, 79(1), 73-95.

Eliwa, Y., Haslam, J. \& Abraham, S. (2016) The association between earnings quality and the cost of equity capital: Evidence from the UK. International Review of Financial Analysis 48, 125-139.

El Ghoul, S., Guedhami, O., Kwok, C., \& Mishra, D. (2011) Does corporate social responsibility affect the cost of capital? Journal of Banking \& Finance 35, 23882406.

Fama, E. F. \& MacBeth, J. D. (1973) Risk, return, and equilibrium: Empirical tests. The Journal of Political Economy 81(3), 607-636.

Feldman, S.J., Soyka, P.A., \& Ameer, P.G. (1997) Does improving a firm's environmental management system and environmental performance result in a higher stock price? Journal of Investing 6, 87-97.

Francis, J., LaFond, R., Olsson, P. \& Schipper, K. (2005) The market pricing of accruals quality. Journal of Accounting and Economics, 39(2), 295-327.

Freeman, R. E. \& Reed, D. L. (1983). Stockholders and Stakeholders: A New Perspective in Corporate Governance. California Management Review 25, 88-106. 
Gebhardt, W. R., Lee, C. \& Swaminathan, B. (2001) Toward an implied cost of capital. Journal of Accounting Research, 39(1), 135-176.

Global Sustainable Investment Alliance (2014), Report on Global Sustainable Investment Review. Available online at: http://www.gsi-alliance.org/wp content/uploads/2015/02/GSIA_Review_download.pdf, accessed on 30/4/2015.

Gode, D. \& Mohanram, P. (2003) Inferring the cost of capital using the Ohlson-Juettner model. Review of Accounting Studies 8(4), pp 399-431.

Gray, R., Kouhy, R. \& Lavers, S. (1995) Corporate Social \& Environmental Reporting: A Review of the Literature: A Longitudinal Study of UK Disclosure. Accounting, Auditing \& Accountability Journal 8, 47-77.

Gray, R., Adams, C. A. \& Owen, D. (1996) Accounting \& Accountability: Changes and Challenges in Corporate Social and Environmental Reporting, Prentice-Hall.

Gray, R. (2005), "Taking a long view on what we now know about social and environmental accountability and reporting”, Electronic Journal of Radical Organisation Theory, 9, 1-31 (special issue on "Theoretical perspectives on sustainability").

Gray, P., Koh, P. S. \& Tong, Y. H. (2009) Accruals quality, information risk and cost of capital: Evidence from Australia. Journal of Business Finance \& Accounting, 36(1-2), 51-72.

Guenster, N., Bauer, R., Derwall, J., \& Koedijk, K. (2011) The economic value of corporate eco-efficiency. European Financial Management 17(4), 679-704.

Gujarati, D. (2003) Basic Econometrics, 4th ed., Boston: McGraw-Hill.

Guthrie, J. \& Parker, L. (1990) Corporate Social Disclosure Practice: A Comparative International Analysis. Advances in Public Interest Accounting 3, 159-175

Hail, L. \& Leuz, C. (2006) International differences in the cost of equity capital: Do legal institutions and securities regulation matter? Journal of Accounting Research, 44(3), 485-531.

Harjoto, M. A., \& Jo, H. (2015) Legal vs. Normative CSR: Differential Impact on Analyst Dispersion, Stock Return Volatility, Cost of Capital, and Firm Value. Journal of Business Ethics, 128, 1-20.

Harrison, J. S. \& Freeman, R. E. (1999) Stakeholders, Social Responsibility \& Performance: Empirical Evidence \& Theoretical Perspectives. Academy of Management Journal, 42, 479-485

Hasseldine, J., Salama, A. and Toms, J. S. (2005) Quantity versus quality: the impact of environmental disclosures on the reputations of UK Plcs. British Accounting Review, 37, 231-248.

Hogan, Janine. \& Lodhia, Sumit. (2011) "Sustainability reporting and reputation risk management: an Australian case study", International Journal of Accounting and Information Management, 19 (3), pp.267-287.

Hughes, K., (2000) The value relevance of non-financial measures of air pollution in the electric industry. The Accounting Review (April), 209-228.

Investment Company Institute. (2010) Equity Ownership in America [Online]. Available: http://www.ici.org/research/stats [Accessed March 2016].

Jiao, Y., (2010) Stakeholder welfare and firm value. Journal of Banking and Finance 34, 2549-2561.

Jensen, M.C. and Meckling, W.H. (1976), “Theory of the firm: managerial behaviour, agency costs and ownership structure”. Journal of Financial Economics, 3, 305-60.

Jo, H., \& Harjoto, M. A. (2011) Corporate Governance and Firm Value: The Impact of Corporate Social Responsibility. Journal of Business Ethics, 103(3), 351-383. 
Klassen, R.D. and McLaughlin, C.P. (1996) 'The impact of environmental management on firm performance’. Management Science, 42 (8), 1199-1214.

Kimbro, Marinilka. \& Cao, Barros Zhiyan. (2011) "Does voluntary corporate citizenship pay? An examination of the UN Global Compact", International Journal of Accounting \& Information Management, 19 (3), pp.288-303.

King, A., \& Lenox, M. (2001) Does it really pay to be green? An empirical study of firm environmental and financial performance. The Journal of Industrial Ecology 5(1), 105-116.

Lang, M., Lines, K. V. \& Maffetti, M. (2012) Transparency, Liquidity, and Valuation: International Evidence on When Transparency Matters Most. Journal of Accounting Research, 50(3), 729-774

Larocque, S. (2013) Analysts' Earnings Forecast Errors and Cost of Equity Capital Estimates. Review of Accounting Studies, 18(1), 135-166.

Lee, Darren D., Faff, Robert W. and Rekker, Saphira A.C. (2013) "Do high and low-ranked sustainability stocks perform differently?", International Journal of Accounting \& Information Management, 21(2), pp.116-132.

Leuz, C., Nanda, D. \& Wysocki, P. D. (2003) Earnings management and investor protection: an international comparison. Journal of financial economics, 69(3), 505-527.

Li, S. \& Liu, C. (2017) Quality of Corporate Social Responsibility Disclosure and Cost of Equity Capital: Lessons from China. Working Paper Avaialabe at https://papers.ssrn.com/sol3/papers.cfm?abstract_id=2917073 accessed on 05/02/2018.

Marquardt, C., \& Wiedman, C. (1998) Voluntary disclosure, information asymmetry, and insider selling through secondary equity offerings. Contemporary Accounting Research 15(4), 505-537.

McGuire, J. B., Sundgren, A. \& Schneeweis, T. (1988) Corporate Social Responsibility and Firm Financial Performance. Academy of Management Journal, 31(4), 854-872.

McWilliams, A., \& Siegel, D. (2000) Corporate Social Responsibility and Financial Performance: Correlation or Misspecification? Strategic Management Journal, 21(5), 603-609.

McWilliams, A., \& Siegel, D., (2001) Corporate Social Responsibility: A Theory of the Firm Perspective. Academy of Management Review, 26(1), 117-127.

Mishra, S. B., \& Suar, D. (2010) Does Corporate Social Responsibility Influence Firm Performance of Indian Companies. Journal of Business Ethics, 95(4), 571-601.

Newey, W. K. \& West, K. D. (1987) A simple, positive semi-definite, heteroskedasticity and autocorrelation consistent covariance matrix. Econometrica: Journal of the Econometric Society, 55(3), 703-708.

Nobes, C., Parker, R. B. \& Parker, R. R. H. (2008) Comparative international accounting: Prentice Hall.

Ness, K. E. and Mirza, A. M. (1991) 'Corporate Social Disclosure: A note on a test of Agency Theory. British Accounting Review, 23, 210-217.

Office for National Statistics. (2010) Ownership of UK Quoted Shares [Online]. Available: http://www.ons.gov.uk/ons/rel/pnfc1/share-ownership---share-register-surveyreport/2010/stb-share-ownership-2010.html [Accessed March 2016].

Ohlson, J. (1995) Earnings, book values, and dividends in equity valuation. Contemporary Accounting Research (Spring), 661-687.

Plumlee, M., Brown, D., Hayes, R., \& Marshall, S. (2015) Voluntary environmental disclosure quality and firm value: Further evidence. Journal of Accounting and Public Policy, 34, 336-361. 
Rogers, J., Skinner, D., \& Van Buskirk, A. (2009) Earnings guidance and market uncertainty. Journal of Accounting and Economics 48(1), 90-109.

Rogers, J., \& Van Buskirk, A. (2009) Shareholder litigation and changes in disclosure behaviour. Journal of Accounting and Economics 47(1/2), 136-156.

Richardson, A., \& Welker, M. (2001) Social disclosure, financial disclosure and the cost of equity capital. Accounting, Organizations and Society 26, 597-616.

Salama, A. (2005) A note on the impact of environmental performance of financial performance. Structural Change and Economic Dynamics, 15, 413-421.

Salama, A., Anderson, A. and Toms, J. S. (2011) Does community and environmental responsibility affect firm risk? Evidence from UK panel data 1994-2006. Business Ethics: A European Review, 20(2), 192-204.

Sharfman, M., \& Fernando, C. (2008) Environmental Risk Management and the Cost of Capital. Strategic Management Journal 29, 569-592.

Solomon, A., Solomon, J. \& Suto, M. (2004) Can the UK experience provide lessons for the evolution of SRI in Japan? Corporate Governance: An International Review, 12(4), 552-566.

Souissi, M., \& Khlif, H. (2012) "Meta-analytic review of disclosure level and cost of equity capital", International Journal of Accounting \& Information Management, 20 (1), pp.49-62.

Sun, N., Salama, A., Hussainey, K. and Habbash, M. (2010),"Corporate environmental disclosure, corporate governance and earnings management", Managerial Auditing Journal, 25 (7) 679-700

Suto, M. and Takehara, H. (2017), “CSR and cost of capital: evidence from Japan”, Social Responsibility Journal, 13 (4), pp. 798-816.

Toms, J.S. (2002) 'Firm resources, quality signals and the determinants of corporate environmental reputation: some UK evidence'. British Accounting Review, 34(3), 257-282.

Williams, C. A. \& Conley, J. M. (2005) An Emerging Third Way-The Erosion of the AngloAmerican Shareholder Value Construct. Cornell International Law Journal, 38, 493551.

World Business Council for Sustainable Development and UNEP Finance Initiative (2010) Key insights for companies and investors. Report from an international workshop series of the WBCSD and UNEP FI, Translating ESG into sustainable business value.

Wooldridge, J. M. (2010) Econometric analysis of cross section and panel data. Cambridge Massachusetts: The MIT Press.

Xu, Shan., Liu, D., \& Huang, J. (2015) Corporate social responsibility, the cost of equity capital and ownership structure: An analysis of Chinese listed firms. Australian Journal of Management 40(2), 245-276.

Yu, Minna. \& Zhao, Ronald. (2015) "Sustainability and firm valuation: an international investigation", International Journal of Accounting and Information Management, 23(3), pp.289-307. 
Figure 1: Formulae for the implied cost of equity capital models

\begin{tabular}{|c|c|c|}
\hline Proxy & Common name & Formula \\
\hline$r_{P E G}$ & $\begin{array}{l}\text { Price-earnings } \\
\text { growth ratio model } \\
\text { (PEG) (Easton, } \\
\text { 2004) }\end{array}$ & $r_{P E G}=\sqrt{\frac{E\left(e p s_{2}\right)-E\left(e p s_{1}\right)}{P_{0}}}$ \\
\hline $\boldsymbol{r}_{\text {MPEG }}$ & $\begin{array}{l}\text { Modified price- } \\
\text { earnings-growth } \\
\text { ratio method } \\
\text { (Easton, 2004) }\end{array}$ & $\begin{array}{c}r_{M P E G}=A+\sqrt{A^{2}+\left(E\left(e p s_{2}\right)-\left(E\left(e p s_{1}\right)\right) / P_{0}\right.} \\
A=E\left(d p s_{1}\right) / 2 P_{0}\end{array}$ \\
\hline$r_{G M}$ & $\begin{array}{l}\text { The modified } \\
\text { economy-wide } \\
\text { growth model } \\
\text { (Gode and } \\
\text { Mohanram, 2003) }\end{array}$ & 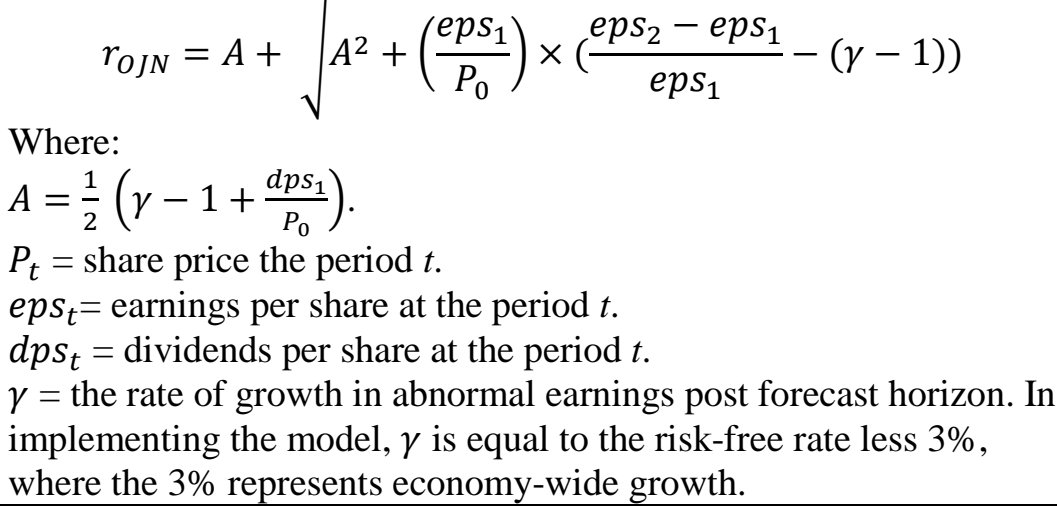 \\
\hline $\boldsymbol{r}_{\text {MEAN }}$ & $\begin{array}{l}\text { Mean implied cost } \\
\text { of capital }\end{array}$ & The mean of $r_{P E G}, r_{M P E G}$ and $r_{G M}$. \\
\hline
\end{tabular}

Table 1: Descriptive Statistics 2010-2014

\begin{tabular}{|lccccc|}
\hline & Mean & S.D. & $\mathbf{2 5 \%}$ & Median & $\mathbf{7 5 \%}$ \\
\hline$r_{\text {(MEAN) }}($ CoEC) & 0.109 & 0.033 & 0.086 & 0.101 & 0.126 \\
CSEP & 6.220 & 0.95 & 5.710 & 6.310 & 6.810 \\
Size (log of total assets) & 14.260 & 1.53 & 13.080 & 14.150 & 15.130 \\
Growth & 0.552 & 1.12 & -0.009 & 0.344 & 0.885 \\
Leverage & 0.211 & 0.1506 & 0.084 & 0.201 & 0.307 \\
Beta (CAPM) & 0.937 & 0.55 & 0.560 & 0.900 & 1.310 \\
Sales $(£ m)$ & 3,900 & 5,800 & 490 & 1,200 & 3,500 \\
Equity $(£ m)$ & 1,900 & 3,600 & 170 & 480 & 1,400 \\
Total Assets $(£ m)$ & 5,200 & 9,800 & 480 & 1,400 & 3,700 \\
\hline
\end{tabular}

Sample description and variable definitions: The sample comprises companies with data on the cost of equity capital (CoEC), CSEP in given years 2010-2014; 552 company-year observations are examined. $r_{\text {Mean }}=$ the average of three ex-ante measures of the cost of equity capital $\left(r_{P E G}, r_{M P E G}\right.$ and $\left.r_{G M}\right)$. Size $=\log$ of total assets in year $t$; Leverage $=$ total interest bearing debt divided by total assets in year $t$; Growth $=\log$ of 1 plus the percentage change in the book value of equity over the preceding 5 years; Beta (CAPM) $=5$-year rolling data acquired from company-specific CAPM estimations using monthly data; it requires a company to have at least 20 monthly observations. 
Table 2: The correlation between earnings quality proxies $r_{P E G}$ and $C S E P$, plus control variables

\begin{tabular}{|l|c|c|c|c|c|}
\hline & $\boldsymbol{r}_{M E A N}$ & CSEP & Size & Growth & Leverage \\
\hline CSEP & $-0.2445^{* * *}$ & 1.00 & & & \\
Gize & $0.0556^{* *}$ & $0.2296^{* * *}$ & 1.00 & & \\
Leverage & $-0.0297^{*}$ & $0.1977^{* * *}$ & -0.0496 & 1.00 & 1.00 \\
Beta & 0.0447 & -0.0218 & $0.0961^{* * *}$ & 0.0200 & 0.0401 \\
\hline
\end{tabular}

Pearson correlations are reported. Significant correlations are shown with *** p-value $<0.01$, ** p-value $<0.05$, $*$ p-value $<0.1 . r_{\text {Mean }}=$ the average of three ex-ante measures of the cost of equity capital $\left(r_{P E G}, r_{M P E G}\right.$ and $\left.r_{G M}\right)$. Size $=\log$ of total assets in year $t$; Leverage $=$ total interest bearing debt divided by total assets in year $t$; Growth $=\log$ of 1 plus the percentage change in the book value of equity over the preceding 5 years; Beta $(\mathrm{CAPM})=5$ year rolling data acquired from company-specific CAPM estimations using monthly data; it requires a company to have at least 20 monthly observations.

Table 3: Regression of $r_{M E A N}$ on CSEP

\begin{tabular}{|c|c|c|c|c|c|c|c|}
\hline & \multirow{2}{*}{$\begin{array}{c}\text { Panel (A) } \\
r_{M E A N}\end{array}$} & \multirow{2}{*}{$\begin{array}{c}\text { Panel (B) } \\
r_{M E A N}\end{array}$} & \multicolumn{5}{|c|}{ Panel (C) } \\
\hline & & & $\begin{array}{c}2010 \\
r_{M E A N}\end{array}$ & $\begin{array}{c}2011 \\
r_{M E A N}\end{array}$ & $\begin{array}{c}2012 \\
r_{M E A N}\end{array}$ & $\begin{array}{c}2013 \\
r_{M E A N}\end{array}$ & $\begin{array}{c}2014 \\
r_{M E A N}\end{array}$ \\
\hline CSEP & $\begin{array}{c}-0.0010^{* * *} \\
(-5.10)\end{array}$ & $\begin{array}{c}-0.0010^{* * *} \\
(-4.91)\end{array}$ & $\begin{array}{c}-0.0015^{* * *} \\
(-3.63)\end{array}$ & $\begin{array}{c}-0.00066 \\
(-1.21)\end{array}$ & $\begin{array}{r}-0.00087^{* *} \\
(-2.10)\end{array}$ & $\begin{array}{c}-0.00051 \\
(-1.62)\end{array}$ & $\begin{array}{r}-0.0014^{* *} \\
(-2.40)\end{array}$ \\
\hline Beta & $\begin{array}{c}0.017^{* * *} \\
(5.63)\end{array}$ & $\begin{array}{c}0.017^{* * *} \\
(7.89)\end{array}$ & $\begin{array}{c}0.019^{* * *} \\
(2.98)\end{array}$ & $\begin{array}{c}0.023^{* * *} \\
(3.05)\end{array}$ & $\begin{array}{l}0.010 \\
(1.57)\end{array}$ & $\begin{array}{c}0.015^{* * *} \\
(2.82)\end{array}$ & $\begin{array}{l}0.016^{*} \\
(1.90)\end{array}$ \\
\hline Size & $\begin{array}{c}0.0018^{*} \\
(1.89)\end{array}$ & $\begin{array}{c}0.0015 \\
(1.77)\end{array}$ & $\begin{array}{c}0.0034 \\
(1.54)\end{array}$ & $\begin{array}{c}0.00031 \\
(0.13)\end{array}$ & $\begin{array}{c}-0.00096 \\
(-0.48)\end{array}$ & $\begin{array}{c}0.0034^{* *} \\
(2.15)\end{array}$ & $\begin{array}{c}0.0014 \\
(0.74)\end{array}$ \\
\hline Growth & $\begin{array}{c}0.0013 \\
(0.96)\end{array}$ & $\begin{array}{c}0.00079 \\
(0.59)\end{array}$ & $\begin{array}{r}-0.00012 \\
(-0.047)\end{array}$ & $\begin{array}{c}0.0020 \\
(0.66)\end{array}$ & $\begin{array}{l}-0.0011 \\
(-0.42)\end{array}$ & $\begin{array}{l}-0.0021 \\
(-0.91)\end{array}$ & $\begin{array}{c}0.0053 \\
(1.08)\end{array}$ \\
\hline Leverage & $\begin{array}{c}-0.0026 \\
(-0.28)\end{array}$ & $\begin{array}{l}-0.0051 \\
(-0.45)\end{array}$ & $\begin{array}{l}0.035^{*} \\
(1.76)\end{array}$ & $\begin{array}{l}-0.026 \\
(-1.23)\end{array}$ & $\begin{array}{l}-0.016 \\
(-0.81)\end{array}$ & $\begin{array}{c}0.0038 \\
(0.22)\end{array}$ & $\begin{array}{l}-0.022 \\
(-0.91)\end{array}$ \\
\hline Constant & $\begin{array}{l}0.12^{* * *} \\
(7.61)\end{array}$ & $\begin{array}{l}0.12^{* * *} \\
(7.19)\end{array}$ & $\begin{array}{l}0.12^{* * *} \\
(3.55)\end{array}$ & $\begin{array}{l}0.13^{* * *} \\
(3.63)\end{array}$ & $\begin{array}{l}0.16^{* * *} \\
(4.82)\end{array}$ & $\begin{array}{c}0.062^{* *} \\
(2.38)\end{array}$ & $\begin{array}{l}0.14^{* * *} \\
(3.70)\end{array}$ \\
\hline $\begin{array}{l}N \\
\text { adj. } R^{2}\end{array}$ & $\begin{array}{l}552 \\
0.14 \\
\end{array}$ & $\begin{array}{l}552 \\
0.14 \\
\end{array}$ & $\begin{array}{c}126 \\
0.211 \\
\end{array}$ & $\begin{array}{c}109 \\
0.127 \\
\end{array}$ & $\begin{array}{c}123 \\
0.044 \\
\end{array}$ & $\begin{array}{c}105 \\
0.150 \\
\end{array}$ & $\begin{array}{c}89 \\
0.073 \\
\end{array}$ \\
\hline
\end{tabular}

See Table 1 for variables definitions. ${ }^{* * *}$ p-value $<0.01$, ** p-value $<0.05$, * p-value $<0.1$.

The sample consists of 552 company-year observations covers from 2010 to 2014. It shows the regressions of $r_{\text {Mean }}$ on the CSEP plus control variables. t-statistics in parentheses and italic. $r_{\text {Mean }}=$ the average of three exante measures of the cost of equity capital $\left(r_{P E G}, r_{M P E G}\right.$ and $\left.r_{G M}\right)$. Size $=\log$ of total assets in year $t$; Leverage $=$ total interest bearing debt divided by total assets in year $t$; Growth $=\log$ of 1 plus the percentage change in the book value of equity over the preceding 5 years; Beta $(\mathrm{CAPM})=5$-year rolling data acquired from companyspecific CAPM estimations using monthly data; it requires a company to have at least 20 monthly observations.

Panel (A) represents the time-series regressions using the Fama and MacBeth (1973) method.

Panel (B) represents the Newey and West (1987) standard errors pooled regression.

Panel (C) represents the Newey and West (1987) standard errors regression in yearly basis. 
Table 4: Regressions of $\mathrm{r}_{\mathrm{PEG}}, \mathrm{r}_{\mathrm{MPEG}}, \mathrm{r}_{\mathrm{GM}}$ on CSEP, with control variables

\begin{tabular}{|l|c|c|c|}
\hline & $\mathbf{( 1 )}$ & $\mathbf{( 2 )}$ & $\mathbf{( 3 )}$ \\
& $\boldsymbol{r}_{\boldsymbol{P E G}}$ & $\boldsymbol{r}_{\boldsymbol{M P E G}}$ & $\boldsymbol{r}_{\mathbf{G M}}$ \\
\hline CSEP & $-0.00088^{* * *}$ & $-0.0013^{* * *}$ & $-0.0014^{* * *}$ \\
Beta & $(-4.23)$ & $(-6.13)$ & $(-6.47)$ \\
& $0.022^{* * *}$ & $0.015^{* * *}$ & $0.016^{* * *}$ \\
Size & $(7.22)$ & $(4.75)$ & $(5.13)$ \\
& 0.0014 & $0.0031^{* * *}$ & $0.0027^{* * *}$ \\
Growth & $(1.49)$ & $(3.29)$ & $(2.81)$ \\
& $0.0023^{*}$ & 0.00079 & 0.0016 \\
Leverage & $(1.67)$ & $(0.57)$ & $(1.16)$ \\
& -0.0075 & -0.0017 & 0.00017 \\
Constant & $(-0.79)$ & $(-0.18)$ & $(0.018)$ \\
& $0.10^{* * *}$ & $0.12^{* * *}$ & $0.14^{* * *}$ \\
\hline$N$ & $(6.51)$ & $(7.68)$ & $(8.19)$ \\
adj. $R^{2}$ & 547 & 548 & 538 \\
\hline
\end{tabular}

The sample ranges between 538 to 548 company-years and covers the period 2010 - 2014. T-Statistics in parentheses and italic. See Figure 1 for the cost of equity capital measurement. Size $=\log$ of total assets in year $t$; Leverage $=$ total interest bearing debt divided by total assets in year $t$; Growth $=\log$ of 1 plus the percentage change in the book value of equity over the preceding 5 years; Beta (CAPM) $=5$-year rolling data acquired from company-specific CAPM estimations using monthly data; it requires a company to have at least 20 monthly observations.

${ }^{* * *}$ p-value $<0.01,{ }^{* *}$ p-value $<0.05,{ }^{*}$ p-value $<0.1$.

Table 5: The Fixed effects regression of $r_{M e a n}, r_{P E G}, r_{M P E G}, r_{G M}$ on CSEP and its components, with control variables

\begin{tabular}{|l|c|c|c|c|}
\hline & Fixed & Fixed & Fixed & Fixed \\
& $\boldsymbol{r}_{\boldsymbol{M} \text { ean }}$ & $\boldsymbol{r}_{\boldsymbol{P E G}}$ & $\boldsymbol{r}_{\boldsymbol{M P E G}}$ & $\boldsymbol{r}_{\boldsymbol{G M}}$ \\
\hline CSEP & $-0.00085^{* * * *}$ & $-0.00068^{* * *}$ & $-0.0010^{* * *}$ & $-0.0011^{* * *}$ \\
& $(-4.07)$ & $(-3.26)^{* * *}$ & $(-4.86)^{* * *}$ & $(-5.17)^{* *}$ \\
Beta & $0.017^{* * *}$ & $0.022^{* * *}$ & $0.015^{* * *}$ & $0.016^{* * *}$ \\
& $(4.53)$ & $(5.94)$ & $(3.93)^{*}$ & $(4.10)$ \\
Gize & 0.0012 & 0.00095 & $0.0023^{*}$ & 0.0022 \\
& $(0.90)$ & $(0.69)^{* *}$ & $(1.69)$ & $(1.55)^{*}$ \\
Leverage & $0.0025^{* *}$ & $0.0029^{* *}$ & 0.0018 & $0.0022^{*}$ \\
& $(2.09)$ & $(2.39)$ & $(1.53)$ & $(1.78)$ \\
Constant & 0.0058 & 0.000060 & 0.0077 & 0.0060 \\
& $(0.51)$ & $(0.0053)$ & $(0.67)$ & $(0.52)$ \\
& $0.120^{* * *}$ & $0.097^{* * *}$ & $0.120^{* * *}$ & $0.130^{* * *}$ \\
$N$ & $(5.86)$ & $(4.71)$ & $(5.79)$ & $(6.24)$ \\
\hline
\end{tabular}

The sample ranges between 538 and 552, $t=2010-2014$. T-Statistics in parentheses and italic. See Figure 1 for the cost of equity capital measurement. $r_{\text {Mean }}=$ the average of three ex-ante measures of the cost of equity capital $\left(r_{P E G}, r_{M P E G}\right.$ and $\left.r_{G M}\right)$. Size $=\log$ of total assets in year $t$; Leverage $=$ total interest bearing debt divided by total assets in year $t$; Growth $=\log$ of 1 plus the percentage change in the book value of equity over the preceding 5 years; Beta $(\mathrm{CAPM})=5$-year rolling data acquired from company-specific CAPM estimations using monthly data; it requires a company to have at least 20 monthly observations.

*** p-value $<0.01,{ }^{* *}$ p-value $<0.05,{ }^{*}$ p-value $<0.1$. 